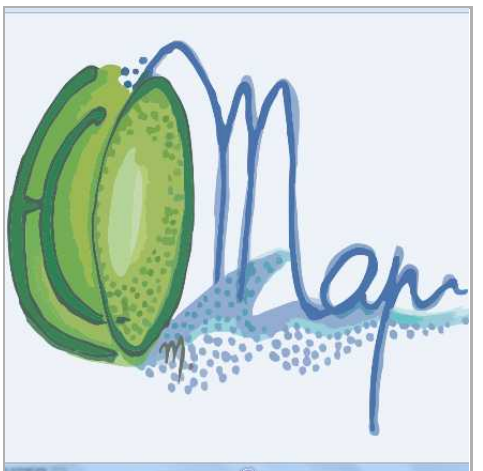

JUL 16, 2021

\title{
(3) nifH amplification for Illumina sequencing
}

Estelle

Bigeard $^{1}$,

\section{Catherine}

Ribeiro ${ }^{3}$

\section{${ }^{1}$ Station Biologique de Roscoff, France; \\ ${ }^{2}$ Asian School of Environment - NTU; ${ }^{3}$ Station Biologique de Roscoff}

Ecology of Marine Plankton (ECOMAP) team - Roscoff

AD2M

\section{open $\boldsymbol{\text { Access }}$}

\section{DOI:}

dx.doi.org/10.17504/protocol s.io.bkipkudn

\section{Protocol Citation: Estelle} Bigeard, Adriana Lopes Dos Santos, Catherine Ribeiro 2021. nifH amplification for Illumina sequencing.

\section{protocols.io}

https://dx.doi.org/10.17504/p rotocols.io.bkipkudn

License: This is an open access protocol distributed under the terms of the Creative Commons Attribution License, which permits unrestricted use, distribution, and reproduction in any medium, provided the original author and source are credited

Protocol status: Working We use this protocol and it's working

Created: Aug 31, 2020

Last Modified: Jul 16, 2021

\section{3}

\section{Keywords: gene} amplification, metabarcoding, NGS, sequencing, diazotrophs

\section{Estelle Bigeard}

Station Biologique de Roscoff, France, UMR7144 CNRS Sorbonne...

\section{ABSTRACT}

For metabarcoding purpose, the first step involves the amplification by PCR of a given gene region (for example V4 or V9 region of 18S rRNA gene) or gene itself if its size does not exceed 600bp (the longest fragment size that can be sequenced by Illumina technology).

The defined forward and reverse primers that are complementary upstream and downstream of the region of interest, needs to be designed with overhang adapters which will be used in a subsequent limited-cycle amplification step, in order to add the dual-index barcodes and Illumina flow cell adapters. To design illumina primers, it will be necessary to know the sequencing method, and therefore the adapters sequence.

The following protocol explains the generation of nifH PCR amplicons. 


\section{GUIDELINES}

Cyanobacterial nifH genes:

-First round: (Attention! This reference has a typo in the nifh2R primer sequence; to order this primer use the correct sequence shown in this section)

Zani S, Mellon MT, Collier JL, Zehr JP. Expression of nifH genes in natural microbial assemblages in Lake George, NY detected with RT-PCR. Appl Environ Microbiol 66: 3119-3124 (2000).

-Second round:

Zehr, J. P. \& Mcreynolds, L.A. Use of degenerate oligonucelotides for amplification of the nifH gene from the marine cyanobacterium Trichodemium thiebautii. Appl.

Environ. Microbiol. 55, 2522-2526 (1989).

\section{MATERIALS}

\section{- PCR amplification}

Primers Quality SePOP in water, stock $100 \mu \mathrm{M}$ - Eurogentec

Primers with Illumina tail Quality NGS Purification RP-HPLC, dried - Eurogentec

Nuclease-Free Water - Invitrogen ${ }^{\text {TM }}$ Ambion ${ }^{\text {TM }}$ - Ref AM9937

HotStart Taq ${ }^{\circledR}$ Master Mix - Qiagen - Ref 203445 (1000 units)

BSA - New England Biolabs - Ref B9000S

KAPA HiFi HotStart ReadyMix ${ }^{\circledR}$ - Roche Diagnostic France - Ref KK2602

nuclease free plate, microtube

\section{- Electrophoresis}

agarose - Interchim - Ref 31272L

Tris-Base - Sigma Aldrich - Ref T6791

Acetic acid - Thermo Fisher Scientific - Ref 11463473

0,5 M EDTA pH 8,0 - Fisher Scientific - Ref 15575-020

Ethidium bromide - Sigma Aldrich - Ref 46065

\section{- Divers}

Tris - Thermo-fisher - Ref AM9855G

EDTA - Thermo-fisher - Ref15575020

Triton x-100 - Sigma Aldrich -ref T8787

\section{Samples : Acid nucleic extraction and quantification}


By working with RNA, another step to transform the RNA in cDNA is necessary.

Quantify and quality-check the final DNA via NanoDrop or Qubit/PicoGreen Method.

The $A 280 / 260$ ratios should be 1.8 or higher and once working with total community extracted DNAs, a concentration of at least $1 \mathrm{ng} / \mu$ Lis desirable to get consistent PCR results. Avoid secondary extractions or clean-ups for inhibitors, until PCRs have truly shown inhibition (example after trying the PCRs by diluting the original DNA and/or adding BSA to the final PCR reaction)many suboptimal DNAs will still work in PCR. A gel can be run to verify integrity of the extracted material, but it is generally unnecessary for PCR-only studies (Figure 1). Some protocols suggest the normalization of the DNA samples concentration prior to the PCR. In our experience, this is not always possible given the low concentration of some samples. The volume of sample added to the PCR can be settled in function of a range of concentrations instead of normalizing all the samples to the same concentration.

Load in agarose gel $0.8 \%, 1 \mu \mathrm{DNA}+$ loading buffer. The limited of DNA detection using EtBr gels is around 10ng.

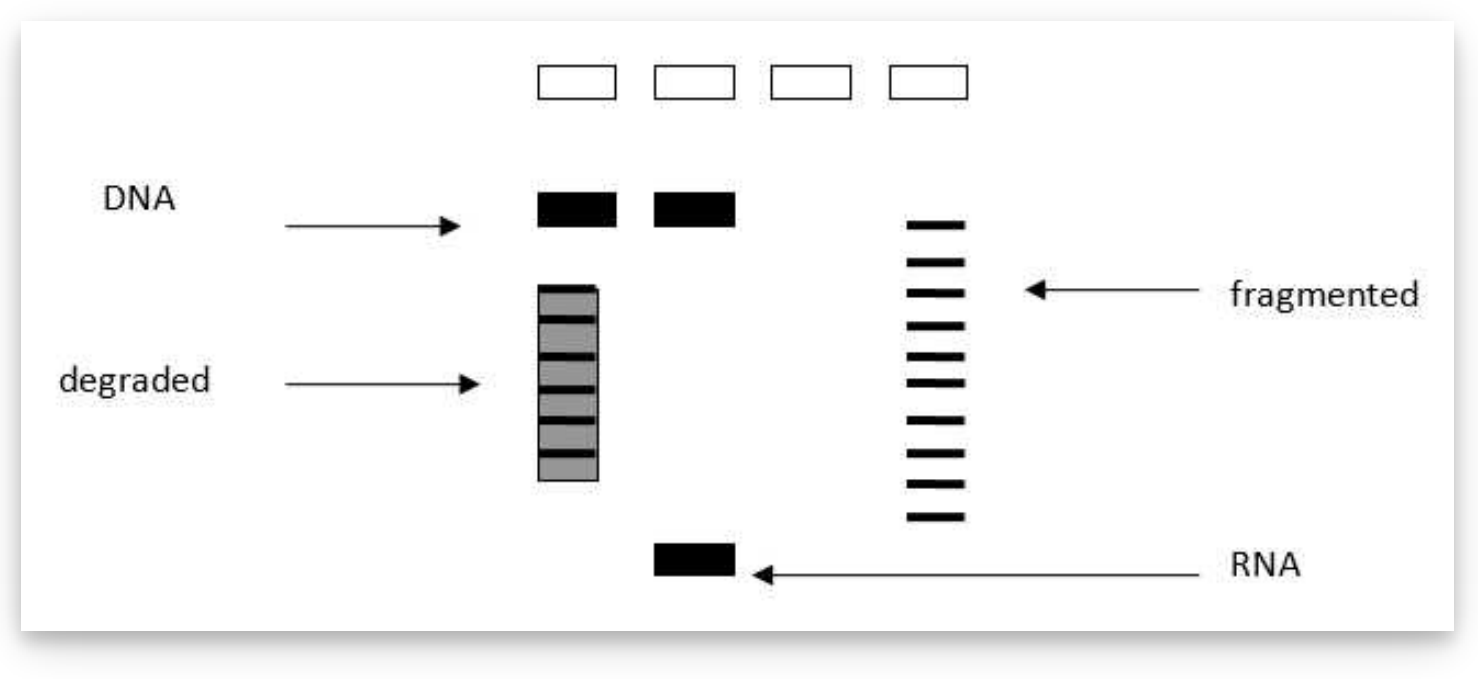

Figure 1: DNA/RNA detection in agarose gel.

Each DNA sample have to be normalized to $5 \mathrm{ng} / \mu \mathrm{l}$ for PCR. For that, dilute DNA in nuclease free water.

It is not necessary to check the DNA concentration after dilution.

Samples with a DNA concentration less than $5 \mathrm{ng} / \mu \mathrm{l}$ will be amplified as is in PCR.

Sorted populations by flow cytometer can be used as an input for the PCR reactions.

Photosynthetic pico and nanoeukaryotes populations selected based on light scatter, orange phycoerythrin and red chlorophyll fluorescence are sorted in sterile eppendorf tubes containing Tris-EDTA lysis buffer (Tris 10 mM, EDTA 1 mM and Triton x-100 1.2\%).The Tris, EDTA and water 
use should be molecular grade. A buffer containing Tris- $\mathrm{HCl} 10 \mathrm{mM}, \mathrm{pH} 8.0$ and $\mathrm{NaCl} 20 \mathrm{mM}$ and filtered at $0.22 \mu \mathrm{m}$ should be used as sheath liquid for marine samples. Sheath fluid samples should be collected and analyzed as negative controls in all subsequent steps including sequencing, in order to test for contamination in the flow sorting process. After the sorting, samples can be stored at $-80 \mathrm{C}$. The DNA from sorted cells can be extracted by three cycles of freezing in liquid nitrogen and thawing in water.

\section{PCR amplification}

2 Below is a suggestion of protocol for nifH amplification from sorted cells and total genomic DNA. This protocol has been tested and used with success.

However, before starting the library preparation, few samples from the batch (es) to be analyze should be selected and the PCR conditions should be tested. The tests can be performed by using the primers without the illumina "tail" which are less expensive since it can be order by normal purification method, like Se-POP. By using also these primers, it avoids excessive manipulation of the primers with the illumina tail and therefore the chances of contamination. Low number of cycles, pool multiple (i.e., triplicate) PCRs for each sample, high initial time of denaturation are fundamental practices for the PCR when targeting diversity studies and should be considered for all reactions, including the tests in order to reduce or avoid PCR bias cause by PCR selection and PCR drift.

- PCR selection includes all mechanisms which inherently favor the amplification of certain templates due to properties of the genes and/or of their flanking sequences of the target region. Potentially important contributors to PCR selection are preferential denaturation due to overall low GC content, higher binding efficiency of GC-rich permutations of degenerate primers, differential accessibility of rRNA genes within genomes, and correlation between amplification probabilities and gene copy numbers within genomes.

- PCR drift is cause by stochastic variation in the early cycles of the reaction (when amplification still proceeds largely from the genomic templates), and its outcome should therefore not be reproducible in replicate PCR amplifications.

More details about these bias can be found in the following references:

-Aird, D. et al. Analyzing and minimizing PCR amplification bias in Illumina sequencing libraries.

Genome Biol. 12, R18 (2011).

-Wagner, A. et al. Surveys of Gene Families Using Polymerase Chain Reaction: PCR Selection and PCR Drift. Syst. Biol. 43, 250 (1994).-Polz, M. F. \& Cavanaugh, C. M. Bias in template-to-product ratios in multitemplate PCR. Appl. Environ. Microbiol. 64, 3724-3730 (1998).

\section{Primers used for DNA amplification and sequencing}

2.1 Use the existing primers (Table 1 \& Table 2) or design your own custom gene primers with the 
proper Illumina indices and Index adaptor orientations. These adapters will be different in function of the libraries preparation protocol, and therefore in function of sequencing platform (Table 2).

Primers for the first round can be order by normal purification method, like Se-POP or RPCartdridge.

It is recommended to order the illumina primers with a good synthesis and purity parameters.

We have order at EUROGENTEC the illumina primers with RP-HPLC purity method, 10 or $40 \mathrm{nmol}$ synthesis scale and at $100 \mu \mathrm{M}$ TE concentration. We could also order in dried and dissolve them with nuclease free water or TE buffer to obtain $100 \mu \mathrm{M}$ stock solution (as described on the Eurogentec's technical data sheet).

Then we dilute them to $10 \mu \mathrm{M}$ working concentration (1/10th the typical $100 \mu \mathrm{M}$ working stock concentration for primers). This proceed should be perform at the PCR hood and with molecular grade water.

\begin{tabular}{l|l|c|l|l}
\hline Target gene & Primer & Product size & Sequence $\left(5^{\prime}-3^{\prime}\right)$ & Reference \\
\cline { 5 - 5 } & & & & \\
\hline \multirow{2}{*}{ nifH (1st round) } & nifH3 & \multirow{2}{*}{473} & ATR TTR TTN GCN GCR TA & Zani et al. 2000 \\
\cline { 5 - 5 } & nifH4 & & TTY TAY GGN AAR GGN GG & Zani et al. 2000 \\
\hline \multirow{2}{*}{ nifH (2 ${ }^{\text {nd }}$ round) } & nifH1F & \multirow{2}{*}{350} & TGY GAY CCN AAR GCN GA & Zehr et al. 1989 \\
\cline { 5 - 5 } & nifH2R & & ADN GCC ATC ATY TCN CC & Zehr et al. 1989 \\
\hline
\end{tabular}

Table 1: Primers used for DNA amplification and sequencing

\begin{tabular}{|c|c|c|c|}
\hline Primer & $\begin{array}{l}\text { Product size } \\
\text { with the tail }\end{array}$ & Sequencing by: & Final Primer (Illumina tail) \\
\hline nifH1F_Illumina & \multirow[t]{2}{*}{471} & \multirow{2}{*}{ Genomer (Roscoff) } & $\begin{array}{l}\text { TCGTCGGCAGCGTCAGATGTGTATAAGAGACAG } \\
\text { TGYGAYCCNAARGCNGA }\end{array}$ \\
\hline nifH2R_Illumina & & & $\begin{array}{l}\text { GTCTCGTGGGCTCGGAGATGTGTATAAGAGACAG } \\
\text { ADNGCCATCATYTCNCC }\end{array}$ \\
\hline nifH1F_Illumina & \multirow[t]{2}{*}{471} & \multirow{2}{*}{ Genotoul } & $\begin{array}{l}\text { CTTTCCCTACACGACGCTCTTCCGATCT } \\
\text { TGYGAYCCNAARGCNGA }\end{array}$ \\
\hline nifH2R_Illumina & & & $\begin{array}{l}\text { GGGAGTTCAGACGTGTGCTCTTCCGATCT } \\
\text { ADNGCCATCATYTCNCC }\end{array}$ \\
\hline
\end{tabular}

Table 2: nifH final primers with Illumina tail

\section{Controles}

2.2 Test a negative control for each series. The negative PCR product could be insert in the library to have a control of air contaminations. 
It is possible to test a positive control (mock communities) to check the sequencing efficacity. For that, you have to select axenic cultures, to know the starting cells concentration and the DNA concentration. We could buy commercial Mock communities (ex: Zymo).

\section{First round}

2.3 Place plates, tubes and nuclease free water under UV to prepare the PCR mix.

nifH amplification need PCR in two rounds, with a second nested PCR.

For the nifH gene, the first round contains:

\begin{tabular}{|l|c|c|c|}
\hline Reagent & $\begin{array}{c}\text { Initial } \\
\text { concentration }\end{array}$ & $\begin{array}{c}\text { Final } \\
\text { concentration }\end{array}$ & Volume \\
\hline nifH3 & $10 \mu \mathrm{M}$ & $0.6 \mu \mathrm{M}$ & $0.9 \mu \mathrm{L}$ \\
\hline nifH4 & $10 \mu \mathrm{M}$ & $0.6 \mu \mathrm{M}$ & $0.9 \mu \mathrm{L}$ \\
\hline HotStart Jag® Master Mix (Qiagen) & $2 \mathrm{x}$ & $1 \mathrm{x}$ & $7.5 \mu \mathrm{L}$ \\
\hline DNA & & & $2 \mu \mathrm{L}$ \\
\hline H2O up to a $15 \mu \mathrm{L}$ reaction & & & $3.7 \mu \mathrm{L}$ \\
\hline
\end{tabular}

Table 3: PCR reaction using HotStart Taq® for first round

\begin{tabular}{|c|c|c|c|c|}
\hline & & Temperature $\left({ }^{\circ} \mathrm{C}\right)$ & Time & \\
\hline \multicolumn{2}{|c|}{ Initial denaturation / Heat activation } & $95^{\circ} \mathrm{C}$ & $15 \min$ & \\
\hline \multirow{3}{*}{ Amplification } & Denaturation & $95^{\circ} \mathrm{C}$ & $1 \mathrm{~min}$ & \multirow{3}{*}{35 cycles } \\
\hline & Annealing & $45^{\circ} \mathrm{C}$ & $1 \mathrm{~min}$ & \\
\hline & Elongation & $72^{\circ} \mathrm{C}$ & $1 \mathrm{~min}$ & \\
\hline \multicolumn{2}{|c|}{ Final elongation } & $72^{\circ} \mathrm{C}$ & $10 \mathrm{~min}$ & \\
\hline
\end{tabular}

Table 4: Thermal conditions using HotStart Taq ${ }^{\circledR}$ for first round

PCRs of the first round are performed in triplicates, pooled and used as template in the second round without checking on agarose gel.

\section{Second round}

2.4 Place plates, tubes and nuclease free water under UV to prepare the PCR mix. 
The second round is performed as follows (in triplicate):

\begin{tabular}{|l|c|c|c|}
\hline Reagent & $\begin{array}{c}\text { Initial } \\
\text { concentration }\end{array}$ & $\begin{array}{c}\text { Final } \\
\text { concentration }\end{array}$ & Volume \\
\hline nifH1F_illumina & $10 \mu \mathrm{M}$ & $0.3 \mu \mathrm{M}$ & $0.75 \mu \mathrm{L}$ \\
\hline nifH2R_illumina & $10 \mu \mathrm{M}$ & $0.3 \mu \mathrm{M}$ & $0.75 \mu \mathrm{L}$ \\
\hline KAPA HiFi HotStart ReadyMix@ & $2 \times$ & $1 \mathrm{x}$ & $12.5 \mu \mathrm{L}$ \\
\hline 1st round product (DNA) & & & $2 \mu \mathrm{L}$ \\
\hline H2O up to a 25 $\mu \mathrm{L}$ reaction & & & $9 \mu \mathrm{L}$ \\
\hline
\end{tabular}

Table 5: PCR reaction using KAPA HiFi HotStart ReadyMix® for the second round

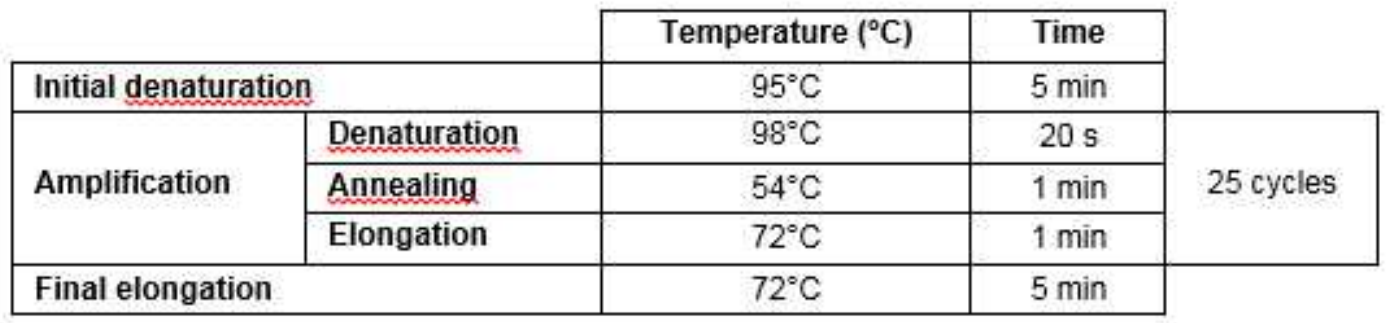

Table 6: Thermal conditions using KAPA HiFi HotStart ReadyMix ${ }^{\circledR}$ for the second round

\section{Gel electrophoresis}

3 PCR products should be checked initially by gel electrophoresis for unspecific amplification and band size.

- Check the PCR products on agarose gel to see if the bands are weak or strong.

Prepare an agarose gel $1-1.5 \%$ in $0.5 X$ TAE buffer

Microwave until the solution is clear (2 minutes)

Stain with $10 \mathrm{uL}$ ethidium bromide (or SYBR-safe dye)

Prepare tray \& comb(s)

Pour gel into tray

When the gel is polymerized, remove comb

Load gel in electrophoresis cuve containing the same 0.5X TAE buffer

Gel must be covered 
Cut one strip of parafilm.

Load 1-2 uL loading dye onto parafilm, one drop per sample

Mix 1 to $3 \mu$ l of each PCR product with loading dye (up \& down 3 times)

Load it in the agarose gel

Load 5 uL of 100 bp ladder into first and/or last well

Close \& Plug in electrodes to power source

Run the migration for $\sim 120 \mathrm{~V}, 30-45$ minutes

- Any samples with failed PCRs (or spurious bands) are re-amplified by optimizing the PCR (further template dilution to 1:100 or using BSA/other additives) to produce correct bands, or purified using a purification kit like "Nuclesopin Gel \& Clean up kit- Macherey-Nagel”.

\section{Preparation of libraries for Illumina sequencing (metabarco.}

4 If the PCR's product are not concentrated enough, you could purify and concentrate them in a smaller volume using a purification and concentration kit like "Nuclesopin Gel \& Clean up kitMacherey-Nagel".

Once PCR products are correct, they are pooled and organized in appropriated PCR plates to generate libraries.

If the illumina sequencing is realized on the Genomer Platform in Roscoff (France), see the protocols.io "Preparation of libraries for Illumina sequencing - Genomer Platform".

If the sequencing is realized by another sequencing service, send to the service pictures of gel to check they are conform (purity, degradation, bands intensity, etc) and follow its protocol. 